\title{
Angiotensin I-Converting Enzyme Gene Polymorphism and Diabetic Nephropathy in Filipino Type 2 Diabetes Mellitus Patients
}

\author{
Elizabeth Paz-Pacheco, ${ }^{1}$ Eva Maria Cutiongco-de la Paz, ${ }^{2}$ Gabriel V. Jasul, Jr. ${ }^{1}$ \\ Ma. Cecille S. Añonuevo-Cruz, ${ }^{1}$ Rhoda L. Montemayor ${ }^{1}$ \\ ${ }^{1}$ Section of Endocrinology, Diabetes and Metabolism; Department of Medicine; \\ University of the Philippines - Philippine General Hospital; Manila, Philippines; \\ Institute of Human Genetics, National Institutes of Health, University of the Philippines Manila, Philippines
}

\begin{abstract}
Objective. Previous studies have demonstrated the role of genetic susceptibility in the pathogenesis of diabetic nephropathy. The study aimed to determine the frequencies of angiotensin l-converting enzyme (ACE) gene insertion/deletion (I/D) polymorphism in a pilot population of Filipino type 2 diabetic patients and normal controls.

Methods. An analysis of the ACE gene polymorphism was performed in 42 diabetic patients with and without nephropathy, and 24 normal controls. The analysis was done using polymerase chain reaction, restriction enzyme digestion, and gel electrophoresis techniques to determine the polymorphism (II, DD or ID). Independent T-tests and chi-square tests were used to compare clinical characteristics, and logistic regression analysis was done to determine odds ratio for development of nephropathy.

Results. The ID polymorphism of the ACE gene was more frequent $(52.4 \%)$ in patients with diabetic nephropathy $(n=21)$. In those without nephropathy $(n=21)$, II was more common $(61.9 \%)$. ID was the more frequent genotype in the normal controls $(n=24)(58.3 \%)$. The odds of developing diabetic nephropathy were increased by 4.8 times in those with ID polymorphism, and 2.9 times in those with DD.

Conclusion. The D allele was more common in patients with diabetic nephropathy, similar to the observation in South Indian patients. Since the study involved only a small pilot group, studies on a larger population is needed to establish the hypothesized role of the D allele in susceptibility to diabetic nephropathy in Filipinos.
\end{abstract}

Keywords: type 2 diabetes mellitus, ACE gene polymorphism, diabetic nephropathy

\section{Introduction}

Diabetic nephropathy occurs in 20 to $40 \%$ of patients with diabetes. ${ }^{1}$ In the Philippines, it is the underlying cause of $38 \%$ of all newly diagnosed renal diseases. ${ }^{2}$

There is considerable evidence supporting the theory that genetic susceptibility plays a major role in the pathogenesis of diabetic nephropathy. ${ }^{3-5}$ One of the genetic modifiers that have been studied in recent years is the angiotensin I-converting enzyme (ACE) gene. The reninangiotensin system (RAS) is believed to contribute significantly to the pathophysiology of kidney disease. ${ }^{6}$ The protein product of the ACE gene is angiotensin Iconverting enzyme, which converts angiotensin I into angiotensin II. Angiotensin II has effects on BP regulation and electrolyte balance because of its potency as a vasopressor and an aldosterone-stimulating peptide. Subsequently, high levels of aldosterone cause increased water and sodium reabsorption and increased

ISSN 0857-1074

Printed in the Philippines

Copyright $@ 2012$ by the JAFES

Received October 9, 2011. Accepted April 11, 2012. extracellular fluid volume. Angiotensin II also decreases circulating levels of bradykinin, which is a potent vasodilator. Individual variance of ACE is mostly determined by the insertion/deletion polymorphism, based on the presence (insertion, $I$ ) or absence (deletion, D) of a 287-bp sequence in intron 16 in chromosome 17. Insertion/deletion polymorphism of this gene produces three genotypes: DD homozygote, II homozygote and ID heterozygote. ${ }^{7,8}$ Previous investigations have demonstrated that this polymorphism accounts for $47 \%$ of the total phenotypic variance of serum ACE, supporting the theory that the ACE gene locus is the major determinant of serum ACE concentration. ${ }^{9}$ The $D$ allele is associated with higher ACE plasma levels, translating to an increased activity of the RAS. Angiotensin induces an increase in intraglomerular pressure and promotes both mesangial cell replication and extracellular matrix accumulation. Glomerular hyperfiltration leads to progressive destruction of nephrons, with characteristic histologic lesions of focal sclerosis. Subsequent proteinuria
Corresponding author: Elizabeth Paz-Pacheco, MD

Section of Endocrinology, Diabetes and Metabolism Department of Medicine

University of the Philippines-Philippine General Hospital

Taft Avenue, Ermita

1000 Manila, Philippines

Telephone number.: + 6325264550

E-mail address: eppacheco@gmail.com 
also leads to tubulointerstitial injury, accelerating the decline in glomerular filtration rate (GFR). ${ }^{10}$ These explain the development of diabetic glomerulopathy and, possibly, the mechanism of renoprotection by ACE inhibitors (ACE-I) and angiotensin II receptor blockers (ARB). ${ }^{11}$

Investigations on the association of the ACE genotype and diabetic nephropathy in diverse ethnic groups have yielded varied results. A meta-analysis done by Tarnow et al showed that the ACE I/D polymorphism plays a major role in genetic susceptibility to diabetic nephropathy in Japanese non-insulin dependent diabetes mellitus (NIDDM) patients, but does not contribute significantly in Caucasians. ${ }^{7}$ A recent study from Taiwan showed a significant association of the ACE DD genotype with diabetic nephropathy. ${ }^{8}$ Similarly, a strong positive association of the $D$ allele (ID and $D D$ genotypes) with diabetic proteinuria was observed in South Indian patients. ${ }^{12}$ A recent meta-analysis on the ACE gene polymorphism in diabetic patients of varied ethnicities showed a reduced risk of diabetic nephropathy associated with the II genotype among Caucasians with either type 1 or type 2 diabetes. For Asians (Chinese, Japanese, Koreans), the association was more marked among type 2 diabetics, with a $35 \%$ reduction in risk of diabetic nephropathy compared to those carrying the $D$ allele. ${ }^{13}$

To date, there is no available data on the ACE genotypes in Filipino diabetic patients. Additional evidence supporting a direct association of ACE gene polymorphism with diabetic nephropathy may help in establishing ACE genotype as a prognostic indicator for diabetes and renal disease, and as a predictor for response to pharmacologic treatment with ACE-I or ARB.

\section{Methods}

\section{Subject selection and recruitment}

Consecutive recruitment of adult Filipino type 2 diabetics consulting at the Diabetes Clinic of a tertiary universityaffiliated government hospital was performed. The American Diabetes Association (ADA) criteria for diagnosis of type 2 diabetes mellitus was applied: 1) symptoms of diabetes plus casual plasma glucose concentration equal to or more than $11.1 \mathrm{mmol} / \mathrm{L}(200$ $\mathrm{mg} / \mathrm{dL}$ ), or 2) fasting plasma glucose (FPG) equal to or more than $7.0 \mathrm{mmol} / \mathrm{L}(126 \mathrm{mg} / \mathrm{dL})$, or 3) two-hour postload glucose equal to or more than $11.1 \mathrm{mmol} / \mathrm{L}(200$ $\mathrm{mg} / \mathrm{dL}$ ) during an oral glucose tolerance test (OGTT) using $75 \mathrm{~g}$ anhydrous glucose. ${ }^{14}$ Normal control was defined as: 1) FPG less than $6.1 \mathrm{mmol} / \mathrm{L}(110 \mathrm{mg} / \mathrm{dL}), 2)$ two-hour postload glucose less than $7.8 \mathrm{mmol} / \mathrm{L}$ (140 mg/dL), 3) no history of diabetes mellitus among first-degree relatives (parents and offspring) and siblings, and 4) age of at least 60 years. The normal controls from a previous study in the same institution were anonymized after efforts to secure re-consent were exhausted. ${ }^{15}$ Patients with type 1 diabetes or established renal disease other than diabetic nephropathy were excluded from the study.

\section{Demographic and clinical characteristics}

After obtaining informed consent from all recruited subjects, the patients were evaluated based on the following parameters: age, sex, duration of diabetes, presence of comorbid illnesses, body mass index (BMI), blood pressure, glycosylated hemoglobin (HbA1c) (BioRad/Diastat) and nephropathy. Diabetic nephropathy was defined as albuminuria equal to or greater than 20 $\mathrm{mg} / \mathrm{L}$ in a spot urine collection (Micral II, Roche) in the absence of heart failure, infection and strenuous activity. ${ }^{16}$

\section{ACE I/D genotyping}

DNA from each blood sample was obtained using the QiAmp Midi Kit (Qiagen, Germany). Nested PCR was performed in a single tube to directly extend the insertion. The first PCR step used primers that amplified intron 16 across the insertion [GIIS: 5' CTC AAG CAC GCC CCT CAC AGG ACT G 3'; GAS: 5' GAT GTG GCC ATC ACA TTC GTC AGA T 3']. The $50-\mu \mathrm{L}$ reaction mixture contained $2 \mathrm{mM} \mathrm{MgCl} 2,0.25 \% \mathrm{DMSO}$, and $2.5 \mathrm{U}$ GOLDSTAR DNA polymerase (Eurogentec, Seraing, Belgium), along with 400-pM primer concentrations. The template DNA was denatured for 1.5 minutes at $95^{\circ} \mathrm{C}$ before undergoing 15 cycles of denaturation for 1 minute at $95^{\circ} \mathrm{C}$, primer annealing for 1 minute at $62^{\circ} \mathrm{C}$, and extension for 1 minute at $72^{\circ} \mathrm{C}$. The mixture was briefly cooled to $4^{\circ} \mathrm{C}$, and GIIS and a primer corresponding to the insertion sequence [FYM: 5' ATC ACG AGG TCA GGA GAT CGA GAC 3'] were added to the mixture. The new mixture underwent another 15 cycles in the same conditions. The first set of primers produced a 561-bp product for the $I$ allele, and a 274-bp product for the $D$ allele (Figure 1). The second set produced a 376-bp fragment only in the presence of the $I$ allele. In this method, the initial amplification of intron 16 allowed greater sensitivity and specificity in detecting the insertion, which is an Alu repeat-type sequence.

\section{Data analyses}

Baseline characteristics were compared using T-tests for continuous variables and chi-square tests for categorical variables. After obtaining the frequency distribution of the ACE genotypes, logistic regression analysis was used to determine the odds ratio.

\section{Ethics}

Ethical approval for the study was obtained from the Research Implementation and Development Office of the University of the Philippines Manila. 


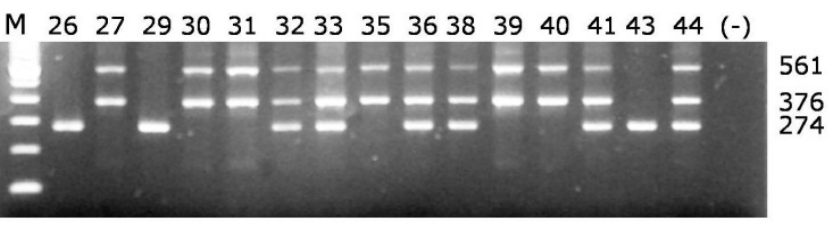

Figure 1. Agarose gels showing the isolated amplified fragments. Numbers on the right column indicate size of amplified fragments in base pairs: 561-bp product for the $I$ allele, 274-bp product for the $D$ allele, and 376-bp fragment for the I allele. Lane 1: $M$, molecular weight ladder; lanes 2-15: \#, patient reference number; lane 16: $(-)$, negative control.

\section{Results}

The baseline characteristics of the patients with and without diabetic nephropathy were significantly different with regard to age (mean of 52 years vs. 60.1 years, $p<0.05$ ) and duration of diabetes mellitus (4.6 vs. 10.2 years, $p<0.05$ ) (Table 1). Unlike in type $1 \mathrm{DM}$, the linkage between duration and nephropathy in type $2 \mathrm{DM}$ is not very clear, largely because of the uncertainty of disease onset. ${ }^{6}$ Other known risk factors for diabetic nephropathy, such as systolic and diastolic blood pressures, glycemic control (as assessed by $\mathrm{HbA1c}$ ) and BMI were not significantly different between the two groups. The ID polymorphism was more frequent in patients with diabetic nephropathy (Table 2). In contrast, the II polymorphism was found in most patients without diabetic nephropathy.

\begin{tabular}{|c|c|c|c|}
\hline & $\begin{array}{c}\text { Without } \\
\text { nephropathy } \\
(n=21)\end{array}$ & $\begin{array}{c}\text { With } \\
\text { nephropathy } \\
(n=21) \\
\end{array}$ & $p$ value \\
\hline Age & 52.0 & 60.1 & $0.0135^{a}$ \\
\hline $\begin{array}{l}\text { Duration of DM } \\
\text { Gender, } \mathrm{n}\end{array}$ & 4.6 & 10.2 & $\begin{array}{c}0.0287^{\mathrm{a}} \\
0.533^{\mathrm{b}}\end{array}$ \\
\hline Male & 8 & 10 & - \\
\hline Female & 13 & 11 & - \\
\hline Weight (kg) & 59.8 & 60.6 & $0.8095^{a}$ \\
\hline Height (m) & 1.545 & 1.583 & $0.2210^{a}$ \\
\hline BMI $\left(\mathrm{kg} / \mathrm{m}^{2}\right)$ & 25.0 & 24.2 & $0.4927^{a}$ \\
\hline $\mathrm{SBP}(\mathrm{mmHg})$ & 121.5 & 119.0 & $0.4964^{a}$ \\
\hline DBP $(\mathrm{mmHg})$ & 77.0 & 78.5 & $0.4180^{\mathrm{a}}$ \\
\hline $\mathrm{A} 1 \mathrm{c}(\%)$ & 8.06 & 7.69 & $0.5219^{\mathrm{a}}$ \\
\hline $\begin{array}{l}{ }^{a} T \text {-test for continuou } \\
{ }^{b} \text { chi-square test for } c \\
\alpha=0.05\end{array}$ & $\begin{array}{l}\text { riables } \\
\text { yorical variables }\end{array}$ & & \\
\hline
\end{tabular}

\begin{tabular}{cccc}
$\begin{array}{l}\text { Table } \\
\text { polymorphisms }\end{array}$ & $\begin{array}{c}\text { 2. Frequency } \\
\text { Control } \\
(\mathbf{n = 2 4 )}\end{array}$ & $\begin{array}{c}\text { Without nephropathy } \\
(\mathbf{n}=\mathbf{2 1})\end{array}$ & $\begin{array}{c}\text { With nephropathy } \\
(\mathbf{n = 2 1 )}\end{array}$ \\
\hline II & $7(29.2)$ & $13(61.9)$ & $6(28.6)$ \\
$I D$ & $14(58.3)$ & $5(23.8)$ & $11(52.4)$ \\
$D D$ & $3(12.5)$ & $3(14.3)$ & $4(19.0)$ \\
\hline
\end{tabular}

Table 3. Odds ratio of diabetic nephropathy

\begin{tabular}{lc}
\hline ACE gene polymorphism & Odds ratio \\
\hline$I D$ & 4.8 \\
$D D$ & 2.9 \\
\hline
\end{tabular}

\section{Discussion}

The study sought to analyze the ACE gene polymorphisms in a small population of Filipino diabetic patients and controls and the risk for developing diabetic nephropathy. The II polymorphism appeared to be more frequent in diabetic patients without nephropathy. In contrast, the $D$ allele was more commonly seen in patients with diabetic nephropathy. These results are similar to but not thoroughly consistent with the findings in the Japanese and South Indian type 2 diabetic patients, and in the meta-analysis of both type 1 and type 2 diabetic patients.7,12,13 Phylogenetic, archaeologic and linguistic data suggest that Filipinos are Austronesian people, a group that includes Southeast Asian, Madagascar and Pacific island ethnicities. Subsequent colonization has also brought limited genetic influences from populations from Europe, America and other parts of Asia. ${ }^{17}$ This may explain the varied findings in genetic studies across close Asian neighbors.

The presence of the $\mathrm{D}$ allele is associated with higher circulating levels of ACE, which is thought to increase the activity of the RAS system. In diabetic individuals who have chronic hyperglycemia leading to endothelial dysfunction, increased stimulation of the RAS system may more likely increase intraglomerular pressure, protein leakage, and subsequent destruction of nephrons. It is interesting to note that the odds of developing diabetic nephropathy were increased close to five-fold in those with ID polymorphism, but only almost three times in those with $D D$ polymorphism. As the population size is small, it is difficult to make valid inferences regarding the possible significance of this heterozygosity in the development of diabetic nephropathy.

The pilot study was limited primarily by its small population size, absence of age- and sex-matched controls, and information pertaining to ethnic background of the subjects. With these findings, it is encouraging to investigate the association of diabetic nephropathy with polymorphisms in the ACE gene in a wider population of Filipino patients.

\section{Conclusion}

The presence of the $D$ allele appears to be the common finding in studies on diabetic nephropathy on Asian populations. Genetic studies on larger populations of type 2 diabetic patients are needed to investigate the hypothesized role of the $D$ allele in susceptibility to the development of nephropathy, to advance the current knowledge of the mechanisms involved in the development of this important cause of renal disease, and to possibly aid in the selection of appropriate therapy for the prevention or delay of progresssion of nephropathy. 


\section{Acknowledgements}

This study was supported by a research grant from the National Institutes of Health (NIH) and the Research Implementation and Development Office of the University of the Philippines Manila.

We thank Mr. Eric Christian Abaya of the Institute of Human Genetics for the genetic analyses and Dr. Dennis Quiambao of the Department of Clinical Epidemiology of the University of the Philippines College of Medicine for the statistical analyses. We would also like to thank Dr. Mia Fojas, Mrs. Au Laurel, Ms. Analyn Palomar, Ms. Rachel Manansala, Ms. Gemma Abquina of the Medical Research Laboratories of the Philippine General Hospital for their assistance.

\section{References}

1. American Diabetes Association. Standards of medical care in diabetes 2006. Diabetes Care 2006;29(Suppl1):S4-42.

2. Renal Disease Control Project (REDCOP). Philippine Renal Disease Registry 2005. Unpublished data.

3. American Diabetes Association. Nephropathy in diabetes. Diabetes Care 2004;27(Suppl1):S79-83.

4. Seaquist ER, Goetz FC, Rich S et al. Familial clustering of diabetic kidney disease: Evidence of genetic susceptibility to diabetic nephropathy. N Engl J Med 1989;320:1161-5.

5. Borch-Johnsen K, Nørgaard K, Hommel E et al. Is diabetic nephropathy an inherited complication? Kidney Int 1992;41:719-2.

6. DeGroot LJ, Jameson JL, eds. Endocrinology. $5^{\text {th }}$ edition. Philadelphia: Elsevier Saunders, 2006.

7. Tarnow L, Gluud C, Parving H. Diabetic nephropathy and the insertion/deletion polymorphism of the angiotensin-converting enzyme gene. Nephrol Dial Transplant 1998;13:1125-30.

8. Hsieh $\mathrm{M}$, Lin $\mathrm{S}$, Hsieh $\mathrm{T}$ et al. Increased frequency of angiotensinconverting enzyme DD genotype in patients with type 2 diabetes in Taiwan. Nephrol Dial Transplant 2000;15:1008-13.
9. Rigat B, Hubert C, Alhenc-Gelas F et al. An insertion/deletion polymorphism in the angiotensin I- converting enzyme gene accounting for half the variance of serum enzyme levels. J Clin Invest 1990;86:1343-6.

10. Brenner BM, Meyer TW, Hostetter TH. Dietary protein intake and the progressive nature of kidney disease: The role of hemodynamically mediated glomerular injury in the pathogenesis of progressive glomerular sclerosis in aging, renal ablation, and intrinsic renal disease. N Engl J Med 1982;307:652-60.

11. Solini A, Vestra MD, Saller A et al. The angiotensin-converting enzyme DD genotype is associated with glomerulopathy lesions in type 2 diabetes. Diabetes 2002;51:251-5.

12. Viswanathan $\mathrm{V}$, Zhu $\mathrm{Y}$, Bala $\mathrm{K}$ et al. Association between ACE gene polymorphism and diabetic nephropathy in South Indian patients. J Pancreas 2001;2(2):83-7.

13. Ng DPK, Tai BC, Koh D et al. Angiotensin-I converting enzyme insertion/deletion polymorphism and its association with diabetic nephropathy: A meta-analysis of studies reported between 1994 and 2004 and comprising 14,727 subjects. Diabetologia 2005;48:1008-16.

14. American Diabetes Association. Diagnosis and classification of diabetes mellitus. Diabetes Care 2004;27(Suppl1):S5-10.

15. Paz-Pacheco E, Cutiongco-de la Paz EMC, Halili-Manabat $C$ et al. Mitochondrial DNA (T/C) 16189 polymorphism, variants and heteroplasmy among Filipinos with type 2 diabetes mellitus. Acta Medica Philippina 2008;42(1):17-21.

16. Mogensen CE, Viberti GC, Peheim E et al. Multicenter evaluation of the Micral-Test II test strip, an immunologic rapid test for the detection of microalbuminuria. Diabetes Care 1997;20(11):1642-6.

17. Cavalli-Sforza LL, Piazza A, Menozzi P, Mountain J. Reconstruction of human evolution: Bringing together genetic, archaeological, and linguistic data. Proc Natl Acad Sci USA 1988;85:6002-6.

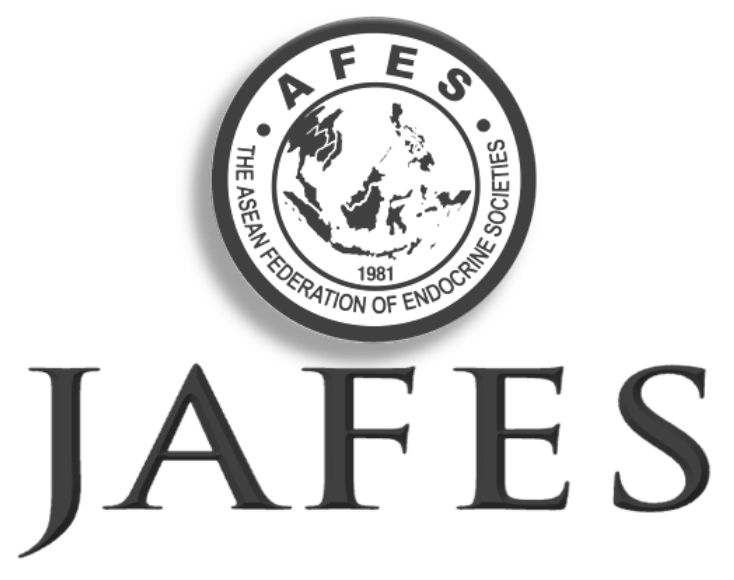

\section{Send your paper to the publication pathway. Instructions to Authors at www.ASEAN-endocrinejournal.org.}

